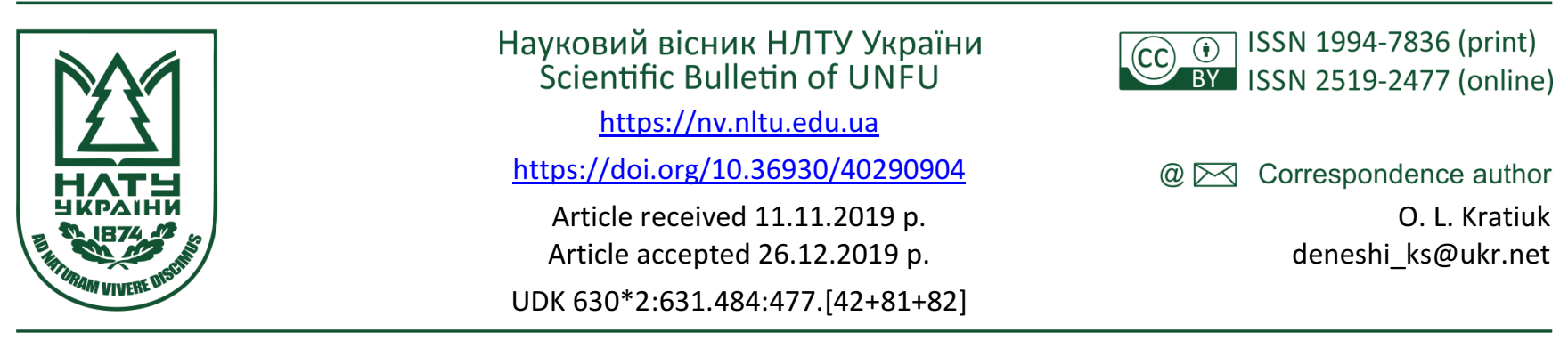

О. Л. Кратюк, М. М. Кравчук, Л. Л. Довбиш

Житомирський наиіональний агроекологічний університет, м. Житомир, Україна

\title{
ВМІСТ ГУМУСУ У ГРУНТАХ ВОЛОГИХ СУГРУДІВ НА ТЕРИТОРІЇ ВОЛЬЄРІВ ЗАХІДНОГО І ЦЕНТРАЛЬНОГО ПОЛІССЯ
}

\begin{abstract}
Встановлено, що в обстежених вольєрах мисливських господарств вміст гумусу низький - 1,9 $9^{ \pm 0,44} \%(n=16)$ і характеризується високим рівнем варіювання ознаки (коефіцієнт варіації $V=47,7 \%$ ). У вольєрі ТОВ "МСК "Сокіл" різниця вмісту гумусу порівняно з контрольними становила $11,8 \%$, у ДП "Білокоровицьке ЛГ" - 10,5 \%, у ТОВ "МРК "Рись" - 41,8 \%, у ТОВ МГ "Сарненське" - 50,2 \%, а у ТОВ "УТМР" - 58,7 \%. У мисливському господарстві ДП "Городницьке ЛГ" спостерігається лише тенденція до покращення показника, а у ДП "Коростишівське ЛГ" різницю між зразками за вмістом гумусу не зафіксовано. Така неоднозначність у накопиченні гумусу в грунті, на нашу думку, зумовлена кількома чинниками: площею вольєра, чисельністю та видовим складом мисливських тварин, тривалістю експлуатації. Упродовж періоду спостережень встановлено чітку лінійну залежність $\left(r=0,99 ; R^{2}=0,98\right)$ між тривалістю функціонування вольєра і вмістом гумусу в шарі $0-20$ см. Така тенденція до накопичення загального гумусу за тривалої експлуатації вольєрів у мисливських господарствах, на наш погляд, пов'язана не тільки 3 надходженням гною від диких тварин, особливо біля підгодівельних майданчиків, але й природним процесом грунтоутворення за гумусово-акумулятивним (дерновим) типом, хоча й у послабленому вигляді. Встановлено, що в обстежених вольєрах у грунтах вологих сугрудів показник $p H_{\text {сол }}$ становить $3,77^{ \pm 0,24}$ (дуже сильнокислі) і характеризується середнім рівнем варіювання ознаки (коефіцієнт варіації $V=12,8 \%$ ). При цьому тривалість та інтенсивність експлуатації вольєрів, а також вид тварин у межах досліджуваних об'єктів не мали істотного впливу на зазначений показник, хоча й виявлено незначну тенденцію до підкислення грунту з часом.
\end{abstract}

Ключові слова: гумусово-акумулятивний процес у лісових ценозах; реакція середовища; тип лісорослинних умов; тип лісу; напіввільне утримання.

Вступ. Основним завданням лісового господарства України є збереження, відтворення та раціональне використання лісових ресурсів. Проте, в умовах ускладнення процесів взаємодії диких тварин, навколишнього середовища та діяльності людини, потрібно забезпечити ефективний моніторинг усіх без винятку складових частин біогеоценозу задля унеможливлення процесів їх деградації. В умовах напіввільного утримання мисливських тварин слабкою ланкою $є$ грунти, які одними 3 перших реагують на мисливсько-господарський тиск. Особливо актуально це в умовах Правобережного Полісся, яке характеризується переважанням у грунтовому покриві відмін легкого гранулометричного складу. За таких умов висока інтенсивність мінералізаційних процесів і кисла реакція грунтового розчину призводять до високої напруженості режиму органічної речовини (Strelchenko \& Kravchuk, 2004). Як наслідок, низький вміст органічної частини в таких грунтах зумовлює їх невисоку екологічну стійкість, обмежує здатність до саморегуляції, а також виконання ними продукційних $\mathrm{i}$

екологічних функцій.

Кожному типу грунту властивий свій критичний (пороговий) рівень вмісту гумусу, при якому значення агрофізичних властивостей грунту (щільність, структурний стан, фізико-механічні властивості) наближаються до таких у грунтотворних порід. Для дерновопідзолистих грунтів критичний рівень гумусу становить менше $1 \%\left(0,6 \% C_{\text {opz. }}\right)$, а для грунтів чорноземного типу - менше $2 \%\left(1,2 \% C_{\text {ор. }}\right)$ від маси (Semenov \& Kogut, 2015). Одним $з$ основних чинників дегуміфікації $є$ біохімічні втрати органічної речовини внаслідок глеє-підзолоутворення (Strelchenko \& Kravchuk, 2004). Вміст органічної речовини нижче від порогового рівня $C_{\text {орг. }}$ У грунті лімітує продуктивність культур, активізуються процеси деградації і погіршуються якості грунту з характерними змінами властивостей і порушенням біогеоценотичних функцій. (Semenov \& Kogut, 2015; Janzen et al., 2012; Loveland \& Webb, 2003). Такі умови ускладнюють формування оптимального агрофізичного стану кореневмісного шару. Тому особливе значення у лісо-

\section{Інформація про авторів:}

Кратюк Олександр Леонідович, канд. біол. наук, доцент, завідувач кафедри експлуатації лісових ресурсів. Email: deneshi_ks@ukr.net; https://orcid.org/0000-0002-2661-8074

Кравчук Микола Миколайович, канд. с.-г. наук, доцент, кафедра ґрунтознавства та землеробства. Email: knzt@i.ua; https://orcid.org/0000-0003-3405-9206

Довбиш Лариса Леонідівна, канд. с.-г. наук, доцент, кафедра ґрунтознавства та землеробства. Email: Ildov@ukr.net; https://orcid.org/0000-0002-0528-145X

Цитування за ДСтУ: Кратюк О. Л., Кравчук М. М., Довбиш Л. Л. Вміст гумусу у ґрунтах вологих сугрудів на території вольєрів Західного і Центрального Полісся. Науковий вісник НЛтУ України. 2019, т. 29, № 9. С. 27-31.

Citation APA: Kratiuk, O. L., Kravchuk, M. M., Dovbysh, L. L. (2019). Humus content in the soils of wet mixed broadleaved forest conditions on the territories of sanctuaries of Western and Central Polissya. Scientific Bulletin of UNFU, 29(9), 27-31. https://doi.org/10.36930/40290904 
вих ценозах належить саме підстилці. Вона сприяє оптимізації грунтових режимів, виконує грунтозахисну роль і $\epsilon$ джерелом поживних речовин та гумусу. Проте у вольєрах обмеженість площі та висока щільність популяцій чинять значний тиск на поверхню грунту та стан лісової підстилки. Основними наслідками деградації $є$ переущільнення, забруднення біогенними елементами, зміна біологічної активності й екологічних функцій (Iurkova, Iurkov \& Smagin, 2008; Kazeev et al., 2018; Zhadobin et al., 2019). Тому потреба оцінити гумусний стан в умовах напіввільного утримання мисливських тварин $є$ актуальним завданням.

Об'єкт дослідження - процес накопичення гумусу у грунтах вологих сугрудів на території вольєрів Західного і Центрального Полісся.

Предмет дослідження - закономірності впливу напіввільного утримання мисливських тварин на гумусний стан і реакцію грунтового розчину.

Мета роботи - встановити закономірності впливу напіввільного утримання мисливських тварин на вміст гумусу у грунтах вологих сугрудів на території вольєрів Західного і Центрального Полісся.
Завдання дослідження: визначити вміст гумусу та реакцію грунтового розчину у грунтах вологих сугрудів на території вольєрів різної тривалості експлуатації та виявити чинники впливу на досліджувані показники.

Матеріали та методи дослідження. Відбір зразків грунту проводили на підгодівельних майданчиках (ділянках найінтенсивнішого впливу мисливської фауни на грунти) у вологих сугрудах на території 7 вольєрів різної тривалості експлуатації, а саме: ТОВ "МСК "Сoкіл", ТОВ МГ "Сарненське" (Західне Полісся), ТОВ "УТМР", ТОВ "МРК "Рись", ДП "Білокоровицьке ЛГ", ДП "Городницьке ЛГ", ДП "Коростишівське ЛГ", (Центральне Полісся) (табл. 1).

У вольєрах утримують кабана дикого (Sus scrofa Linnaeus, 1758), оленів благородного (Cervus elaphus Linnaeus, 1758) та плямистого (Cervus nippon Temminck, 1838), лань (Dama dama Linnaeus, 1758), козулю європейську (Capreolus capreolus Linnaeus, 1758), муфлона європейського (Ovis ammon Linnaeus, 1758). Контрольні зразки відбирали у насадженнях з аналогічними лісівничо-таксаційними показниками поза межами вольєрів. Докладну характеристику місць взяття проб подано у табл. 2.

Табл. 1. Характеристика вольєрів

\begin{tabular}{|c|c|c|c|c|c|}
\hline $\begin{array}{c}\text { № } \\
\text { 3/п }\end{array}$ & Користувач & Вид тварин & $\begin{array}{c}\text { Площа } \\
\text { вольера, } \\
\text { га }\end{array}$ & $\begin{array}{c}\text { Рік } \\
\text { створення }\end{array}$ & $\begin{array}{c}\text { Орієнтовна ність тварин, особин } \\
\text { нисель }\end{array}$ \\
\hline 1 & ТОВ "МСК "Сокіл" & Cervus elaphus, Dama dama, Ovis ammon & 382,3 & 2015 & 250 \\
\hline 2 & ДП "Білокоровицьке ЛГ" & Sus scrofa & 70,5 & 2012 & 50 \\
\hline 3 & ДП "Городницьке ЛГ" & Sus scrofa & 1,5 & 2012 & $\begin{array}{c}32017 \text { р. не функці- } \\
\text { онує }\end{array}$ \\
\hline 4 & ДП "Коростишівське ЛГ" & Sus scrofa & 1,5 & 2012 & $\begin{array}{c}32017 \text { р. не функці- } \\
\text { онує }\end{array}$ \\
\hline 5 & ТОВ "УТМР" & Ovis ammon, Dama dama, Cervus elaphus, Sus scrofa & 29,0 & 1986 & 40 \\
\hline 6 & ТОВ МГ "Сарненське" & Ovis ammon, Dama dama, Capreolus capreolus & 30,0 & 1980 & 45 \\
\hline 7 & ТОВ "МРК "Рись" & Sus scrofa, Ovis ammon, Capreolus capreolus & 34,6 & 1977 & 30 \\
\hline
\end{tabular}

Табл. 2. Лісівничо-таксаційна характеристика насаджень у місці відбору грунтових проб

\begin{tabular}{|c|c|c|c|c|c|c|c|}
\hline $\begin{array}{l}\text { № } \\
\text { 3/П }\end{array}$ & Користувач & Лісництво, квартал (виділ) & Склад деревостану & Тип лісу & \begin{tabular}{|c|} 
Вік, ро- \\
ків
\end{tabular} & $\begin{array}{c}\text { Відносна } \\
\text { повнота }\end{array}$ & $\begin{array}{c}\text { Клас бо- } \\
\text { нітету }\end{array}$ \\
\hline 1 & ТОВ "МСК "Сокіл" & Суське, 16 (31) & 9С31Гз+БП+Дз & $\mathrm{C}_{3}$-гдС & 54 & 0,7 & $\mathrm{I}^{\mathrm{a}}$ \\
\hline 2 & Контроль & Суське, 7 (22) & $8 \mathrm{C}_{3} 2 \Gamma_{3}+Д 3+Б \Pi$ & $\mathrm{C}_{3}$-гдС & 55 & 0,7 & $\mathrm{I}^{\mathrm{a}}$ \\
\hline 3 & ДП "Білокоровицьке ЛГ" & Білокоровицьке, 70 (16) & 4Дз3Бп2Влч1Ос & $\mathrm{C}_{3}$-гД & 71 & 0,7 & II \\
\hline 4 & Контроль & Білокоровицьке, 70 (16) & 4Дз3Бп2Влч1Ос & $\mathrm{C}_{3}$-гД & 71 & 0,7 & II \\
\hline 5 & ДП "Городницьке ЛГ" & Надслучанське, 12 (19) & 10Ялє+Дз+Гз+Бп+Ос & $\mathrm{C}_{3}$-гД & 41 & 0,8 & $\mathrm{I}^{\mathrm{a}}$ \\
\hline 6 & Контроль & Надслучанське, 12 (22) & 10Ялє+Дз+Гз & $\mathrm{C}_{3}$-гД & 37 & 0,8 & $\mathrm{I}^{\mathrm{a}}$ \\
\hline 7 & ДП "Коростишівське ЛГ" & Коростишівське, 19 (8) & 7Дз2Сз1Влч+Бп & $\mathrm{C}_{3}$-гдС & 106 & 0,65 & $\mathrm{I}$ \\
\hline 8 & Контроль & Коростишівське, 19 (8) & 7Дз2Сз1Влч+Бп & $\mathrm{C}_{3}$-гдС & 106 & 0,65 & I \\
\hline 9 & ДП "Коростишівське ЛГ" & Коростишівське, 19 (16) & 9Сз1Влч+Бп & $\mathrm{C}_{3}$-гдС & 50 & 0,65 & $\mathrm{I}^{6}$ \\
\hline 10 & Контроль & Коростишівське, 19 (16) & 9Сз1Влч+БП & $\mathrm{C}_{3}$-гдС & 50 & 0,65 & $\mathrm{I}^{6}$ \\
\hline 11 & TOB "УTMP" & Новозаводське, 36 (23) & $10 \mathrm{C}_{3}+Д 3+В л ч$ & $\mathrm{C}_{3}$-гдС & 80 & 0,7 & $\mathrm{I}^{\mathrm{a}}$ \\
\hline 12 & Контроль & Новозаводське, 36 (3) & $10 \mathrm{C}_{3}+Д 3$ & $\mathrm{C}_{3}$-гдС & 65 & 0,7 & $\mathrm{I}^{\mathrm{a}}$ \\
\hline 13 & ТОВ МГ "Сарненське" & Костянтинівське, 31 (22) & 7Бп2Ос1Гз+Дз+Влч & $\mathrm{C}_{3}$-гД & 50 & 0,5 & I \\
\hline 14 & Контроль & Костянтинівське, 47 (18) & 9Бп1Влч & $\mathrm{C}_{3}$-гД & 50 & 0,7 & $\mathrm{I}^{\mathrm{a}}$ \\
\hline 15. & ТОВ "МРК "Рись" & Пищівське, 92 (16) & 6Дз2Влч1Сз1Бп & $\mathrm{C}_{3}-г$ Д & 135 & 0,5 & III \\
\hline 16 & Контроль & Пищівське, 92 (34) & 5Дз2Бп2Влч1С3 & $\mathrm{C}_{3}$-гД & 76 & 0,6 & I \\
\hline
\end{tabular}

Примітка: * Сз - сосна звичайна, Дз - дуб звичайний, Ялє - ялина європейська, Влч - вільха чорна, Гз - граб звичайний, Oc - осика, Бп - береза повисла. ** для пробних площ 3-4, 7-8, 9-10 лісівничо-таксаційні показники однакові, оскільки таксаційні виділи були розділені під час будівництва вольєрів.

Аналіз гумусного стану грунтів здійснено на підставі результатів лабораторних досліджень, виконаних у вимірювальній лабораторії ННЦ екології та охорони навколишнього середовища Житомирського національного агроекологічного університету. Відбір зразків виконували у 2019 р. за загальноприйнятими мето- диками з шару 0-20 см (DSTU ISO 10381-2:2004, 2006). Загальний гумус визначали за методикою Тюріна

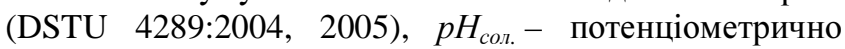
(GOST 26483-85, 1985). Статистичне опрацювання даних виконано за Б. А. Доспєховим (Dospekhov, 1985) 3 використанням пакету програм "Statistica 10". 
Результати дослідження та їх обговорення. Вологі сугруди домінують у вольєрах Центрального Полісся (33,1 \% або 158,1 га) та представлені трьома типами ліcy $\mathrm{C}_{3}$-гдС (100,1 га), $\mathrm{C}_{3}$-гД (55,9 га) та $\mathrm{C}_{3}$-дГ (2,1 га) (Kratiuk, 2019a). Великі площі вологих сугрудів і у межах вольєрів Західного Полісся. Тут вони представлені чотирма типами лісу ( $\mathrm{C}_{3}$-гдС (159,4 га), $\mathrm{C}_{3}$-гД (36,4 га), $\mathrm{C}_{3}$-ягС (5,8 га), $\mathrm{C}_{3}$-гсД (1,0 га)) та загалом займають площу 202,6 га (17,9 \%) (Kratiuk, 2019b).

Встановлено, що в обстежених вольєрах мисливських господарств вміст гумусу низький $-1,90^{ \pm 0,44} \%$ $(n=16)$ і характеризується значним рівнем варіювання ознаки (коефіцієнт варіації $V=47,7 \%$ ). Такий рівень варіювання потребував додаткового обгрунтування, оскільки для аналізу відбирали лише об'єкти, які належать до вологих сугрудів. Окрім цього, передумовою наших досліджень було ймовірне погіршення гумусного стану грунту у вольєрах внаслідок витоптування і часткового знищення лісової підстилки, як захисного шару і джерела для утворення гумусу. Проте вміст гумусу у зразках грунту, які відбирали у вольєрах ТОВ "МРК "Рись", ТОВ МГ "Сарненське", ТОВ "УТМР", був істотно більшим (відповідно на 41,8 \%, 50,2 \% та 58,7 \%), порівняно зі зразками, що були відібрані за межами вольєрів $\left(t_{\phi}=3,18 ; t_{05}=2,78\right)$ (рис. 1$)$. Натомість у вольєрі ТОВ "МСК "Сокіл" різниця становила 11,8 \%, ДП "Білокоровицьке ЛГ" - 10,5 \%, у вольєрі ДП "Городницьке ЛГ" спостерігається лише тенденція до покращення показника, а у ДП "Коростишівське ЛГ" різниця між зразками за вмістом гумусу не зафіксована.

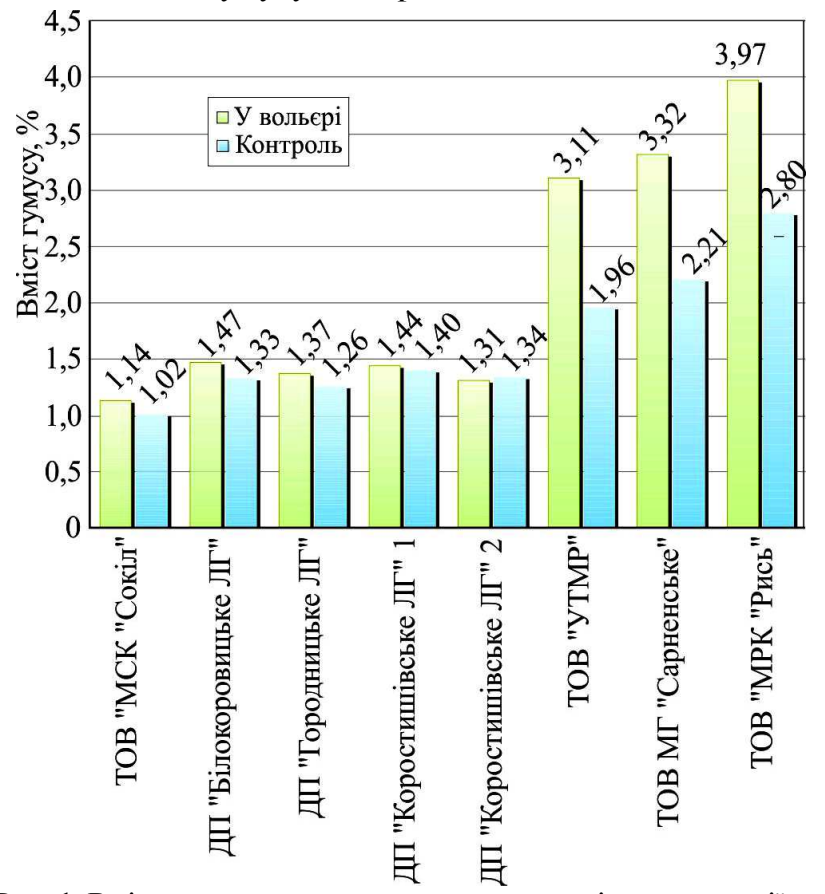

Рис. 1. Вміст гумусу в грунтах вологих сугрудів на території вольєрів Західного і Центрального Полісся, \%

Така неоднозначність у накопиченні гумусу в грунті, на нашу думку, зумовлена кількома чинниками: площею вольєра, чисельністю та видовим складом мисливських тварин, тривалістю експлуатації. Взявши до уваги ці показники, ми виділили три групи вольєрів за ступенем впливу на грунти напіввільного утримання мисливських тварин. До першої групи зі слабким впливом віднесли вольєри ДП "Городницьке ЛГ" та ДП "Коростишівське ЛГ", до другої групи (середній вплив) -
ТОВ "МСК "Сокіл" та ДП "Білокоровицьке ЛГ" і до третьої групи (сильний вплив) - ТОВ "МРК "Рись", ТОВ МГ "Сарненське", ТОВ "УТМР". Загалом між показниками вмісту гумусу першої і другої груп немає достовірної різниці $\left(t_{\phi}=0,52 ; t_{05}=3,18\right)$, оскільки, на нашу думку, незважаючи на різний ступінь впливу мисливської фауни, їх термін експлуатації незначний і становить 4-7 років.

Також важливо було порівняти запаси гумусу у грунтах вольєрів різного терміну закладання. Хоча таке порівняння $є$ дещо умовним, оскільки потребує ретельного підбору грунтових зразків, які повинні відбиратись у схожих умовах за лісівничо-таксаційними та іншими характеристиками, проте воно може вказати на загальну тенденцію до зміни показника у конкретних лісівничо-таксаційних умовах упродовж тривалого часу. Термін експлуатації вольєрів ТОВ "УТМР", ТОВ МГ "Сарненське", ТОВ "МРК "Рись" становить відповідно 33, 39 та 42 роки, а вміст гумусу - 3,11-3,97\%, що значно перевищує показники в інших вольєрах $\left(t_{\phi}=10,37\right.$; $\left.t_{05}=2,45\right)$. Аналізуючи результати агрохімічних показників, встановлено чітку лінійну залежність між тривалістю функціонування вольєра і вмістом гумусу в шарі 0-20 см, яка описується таким лінійним рівнянням (рис. 2):

Humus $=0,90732+0,06761 \cdot \operatorname{EDS} ;\left(r=0,99 ; R^{2}=0,98\right)$, де: Humus - вміст гумусу, \%; EDS - тривалість функціонування вольєра, років.

Така тенденція до накопичення загального гумусу за тривалої експлуатації вольєрів у мисливських господарствах, на наш погляд, пов'язана не тільки з надходженням гною від диких тварин, особливо біля підгодівельних майданчиків, але й природним процесом грунтоутворення за гумусово-акумулятивним (дерновим) типом хоча й у послабленому вигляді. Аналіз вказує на чітку тенденцію до накопичення гумусу в грунтах вологих сугрудів, навіть поза вольєрами (див. рис. 1).

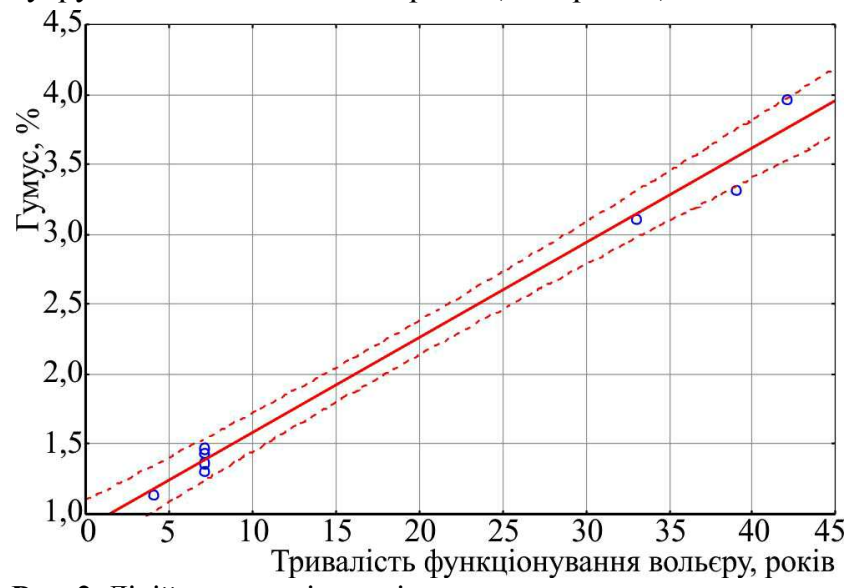

Рис. 2. Лінійна залежність вмісту гумусу в грунтах вологих сугрудів на території вольєрів від тривалості їх експлуатації

Процес гумусонакопичення у лісових ценозах за таких умов супроводжується посиленням диференціації гумусового горизонту (Vladychenskii et al., 2013; Tykhonenko, Novosad \& Havva, 2013). Дерновий процес грунтоутворення максимально проявляється під трав'янистими ценозами і слабше - під листяними деревними породами. Він характеризується накопиченням гумусу та біофільних елементів. На покращення показників грунту під листяними насадженнями вказують і Д. Г. Тихоненко та ін. (Tykhonenko et al., 2013). Вони зазначають, 
що заліснення орних чорноземів (40-65 років) призводить до поліпшення всіх показників грунтової родючості (вмісту поживних речовин, гумусу, обмінного кальцію), відповідної зміни біологічної активності та оптимізації структурно-агрегатного стану грунтової маси, що майже однотипно з дією трав'яних ценозів (Tykhonenko et al., 2013).

На режим органічної речовини значний вплив має реакція грунтового розчину (Litvinovich \& Pavlova, 2010; Heiskanen et al., 2018). Вона визначає характер біогенної трансформації органічної речовини у лісових ценозах (Zhang et al., 2014). Оскільки зональні грунти Полісся характеризуються кислою реакцією і не насичені основами (Halych \& Strelchenko, 2004), у хвойних лісових насадженнях кислотність зростає, інтенсивність бактеріального розкладу лісового опаду пригнічується грибною мікрофлорою і вміст гумусу тяжіє до порогових значень. 3 іншого боку, у листяних насадженнях кислотність закономірно знижується, а вміст гумусу зростає (Iurenia et al., 2010). 3 огляду на це, важливим було проаналізувати й основні фізико-хімічні властивості грунту вольєрів мисливських господарств, зокрема рівень обмінної кислотності.

Встановлено, що в обстежених мисливських госпо-

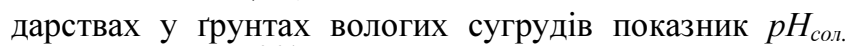
становить $3,77^{ \pm 0,24}$ (дуже сильнокислі) i характеризується середнім рівнем варіювання ознаки (коефіцієнт варіації $V=12,8 \%$ ). При цьому, тривалість та інтенсивність експлуатації вольєрів, а також вид тварин у межах досліджуваних об'єктів не мали істотного впливу на зазначений показник, хоча й спостерігається незначна тенденція до підкислення грунту з часом. Це корелює 3 висновками Д. Г. Тихоненко та ін. (Tykhonenko et al., 2013), отриманими на чорноземах, які зазнали заліснення.

Висновки. Отже, грунти вологих сугрудів на території вольєрів мисливських господарств Західного і Центрального Полісся характеризуються низьким вмістом гумусу - $1,9^{ \pm 0,44} \%$ і значним рівнем варіювання ознаки (коефіцієнт варіації $V=47,7 \%$ ).

Вольєрне утримання тварин на території мисливських господарств Західного і Центрального Полісся забезпечило позитивну тенденцію до накопичення гумусу за тривалої експлуатації вольєрів. Так, у зразках грунту, які відбирали у вольєрах ТОВ МГ "Сарненське", ТОВ "УТМР", ТОВ "МРК "Рись", вміст гумусу був істотно вищим, порівняно зі зразками, що були відібрані за межами вольєрів - приріст становив 41,8-58,7\%, що пов'язано не тільки 3 надходженням гною від диких тварин, особливо біля підгодівельних майданчиків, але й природним процесом грунтоутворення за гумусово-акумулятивним (дерновим) типом. У вольєрах зі слабким ступенем впливу тварин (ДП "Городницьке ЛГ" та ДП "Коростишівське ЛГ") різниця між зразками за вмістом гумусу не зафіксована, або на рівні тенденційного покращення показника.

Грунти обстежених вольєрів характеризуються сильнокислою реакцією $\left(p H_{\text {сол. }}=3,8^{ \pm 0,24}\right)$. При цьому, тривалість та інтенсивність експлуатації вольєрів, а також вид тварин у межах досліджуваних об'єктів не мали істотного впливу на зазначений показник.

Перспективи подальших досліджень полягають в аналізі змін агрофізичних показників, що відбуваються iз грунтом за інтенсивного вольєрного утримання тварин у мисливських господарствах, а також в уточненні динаміки лабільних форм органічної частини грунту, зокрема детриту.

\section{References}

Dospekhov, B. A. (1985). Methods of field experiment (with the basics of statistical processing of research results). Moscow: Agropromizdat. [In Russian].

DSTU 4289:2004. (2005). Soil quality. Methods for determination of organic matter. Kyiv: Derzhspozhyvstandart Ukrainy. [In Ukrainian].

DSTU ISO 10381-2:2004. (2006). ISO 10381-2:2002, IDT. Soil quality. Sampling. Guidance on sampling techniques. (Part 2). Kyiv: Derzhspozhyvstandart Ukrainy. [In Ukrainian].

GOST 26483-85. (1985). Soils. Preparation of salt extract and determination of its $\mathrm{pH}$ by CINAO method. Moscow: Ministerstvo selskogo khoziaistva SSSR. [In Russian].

Halych, M. A., \& Strelchenko, V. P. (2004). Ahroekolohichni osnovy vykorystannia zemelnykh resursiv Zhytomyrshchyny. Zhytomyr: Volyn. [In Ukrainian].

Heiskanen, J., Hallikainen, V., Uusitalo, J., \& Ilvesniemi, H. (2018). Co-variation relations of physical soil properties and site characteristics of Finnish upland forests. Silva Fennica, 52(3), 18. (Article id 9948). https://doi.org/10.14214/sf.9948

Iurenia, A. V., Sokolovskii, I. V., Gerasimenko, M. V., \& Mikulich, D. L. (2010). Svoistva pochv, produktivnost i sostav dubovoelovykh iskusstvennykh nasazhdenii. (Ser. 1: Lesnoe khoziaistvo). Trudy BGTU, 18, 222-224. [In Russian].

Iurkova, N. E., Iurkov, A. M., \& Smagin, A. V. (2008). Otcenka funktcionalnogo sostoianiia pochv Moskovskogo zooparka po mikrobiologicheskim pokazateliam. (Ser. 17: Pochvovedenie). Bulletin of the Moscow University, 3, 39-44. Retrieved from: https://cyberleninka.ru/article/n/otsenka-funktsionalnogo-

sostoyaniya-pochv-moskovskogo-zooparka-pomikrobiologicheskim-pokazatelyam. [In Russian].

Janzen, H. H., Olson, B. M., Zvomuya, F., Larney, F. J., \& Ellert, B. H. (2012). Long-term field bioassay of soil quality. Prairie Soils and Crops J, 5, 165-168. Retrieved from: https://prairiesoilsandcrops.ca/articles/volume-5-17-screen.pdf.

Kazeev, K. Sh., Zhadobin, A. V., Lesina, A. L., Aleksandrov, A. A., Bakaeva, Iu. S., Kravtcova, N. E., \& Kolesnikov, S. I. (2018). Ekologicheskoe sostoianie pochv volerov s zhivotnymi i ptitcami Rostovskogo zooparka. AgroEkoInfo, 3. Retrieved from: https://agroecoinfo.narod.ru/journal/STATYI/2018/3/st 358.doc. [In Russian].

Kratiuk, O. L. (2019a). Typological structure of forest plantations and biotopic characteristics of enclosures in Central Polissya. Scientific $\begin{array}{llll}\text { Bulletin of } & \text { 6NFU, }\end{array}$ https://doi.org/10.15421/40290212

Kratiuk, O. L. (2019b). Forest taxation characteristic of tree stands in the sanctuaries of Western Polissya. Scientific Bulletin of UNFU, 29(6), 45-48. https://doi.org/10.15421/40290609

Litvinovich, A. V., \& Pavlova, O. Yu. (2010). Transformation of the humus composition in light-textured soddy-podzolic soils as affected by increasing lime doses and in the postagrogenic period. Eurasian Soil Science, 43(11), 1263-1270. https://doi.org/10.1134/S1064229310110098

Loveland, P., \& Webb, J. (2003). Is there a critical level of organic matter in the agricultural soils of temperate regions: a review. Soil and Tillage Research, 70, 1-18. https://doi.org/10.1016/S01671987(02)00139-3

Semenov, V. M., \& Kogut, B. M. (2015). Pochvennoe organicheskoe veshchestvo. Moscow: GEOS. [In Russian].

Strelchenko, V. P., \& Kravchuk, M. M. (2004). Vplyv hleiovoho protsesu na dehumifikatsiiu dernovo-pidzolystykh gruntiv. Bulletin of agrarian science, 7, 18-20. [In Ukrainian].

Tykhonenko, D., Novosad, K., \& Havva, D. (2013). Evoliutsiia chornozemiv ahrohennoho i postahrohennoho vykorystannia Livobe- 
rezhnoho Lisostepu Ukrainy. (Ser. Geographically). Bulletin of the University of Lviv, 44, 356-363. [In Ukrainian].

Vladychenskii, A. S., Telesnina, V. M., Rumyantseva, K. A., \& Chalaya, T. A. (2013). Organic matter and biological activity of postagrogenic soils in the southern taiga using the example of Kostroma oblast. Eurasian Soil Science, 46(5), 518-529. https://doi.org/10.7868/S0032180X1305016X

Zhadobin, A. V., Kazeev, K. Sh., Lesina, A. L., Aleksandrov, A. A., Kravtsova, N. E., \& Kolesnikov, S. I. (2019). Assessment of the ecological condition of soils in Rostov zoo. PNRPU. Applied ecology. Urban development, 1, 131-141. https://doi.org/10.15593/2409-5125/2019.01.09

Zhang, X., Liu, Z., Bing, Y., Zhu, B., Trung, L., \& Chen, K. (2014). Dissimilation of soil humus in forest with pure stands and its relationship with other bio-chemical properties in the semi-arid windy region of the Loess Plateau, China, Forestry Studies, 60(1), 24-33. https://doi.org/10.2478/fsmu-2014-0002

O. L. Kratiuk, M. M. Kravchuk, L. L. Dovbysh

Zhytomyr National Agroecological University, Zhytomyr, Ukraine

\section{HUMUS CONTENT IN THE SOILS OF WET MIXED BROADLEAVED FOREST CONDITIONS ON THE TERRITORIES OF SANCTUARIES OF WESTERN AND CENTRAL POLISSYA}

In the conditions of semi-free maintenance of game animals, soils are considered to be the weak link, as they are one of the first to respond to hunting and economic pressure. This is especially true in the conditions of the Right-bank Polissya, which is characterized by the predominance of light granulometric composition in the soil cover. Under such conditions, the high intensity of mineralization processes and the acidic reaction of the soil solution cause a high intensity of the organic matter regime. Sampling of soil was carried out in wet mixed broadleved forest conditions in the territory of 7 sanctuaries such as Sokil HPF LLC, Sarnenske HF LLC (Western Polissya), UTMR LLC, Rys HFC LLC, Bilotserkivske Forestry SOE, Horodnytskey Forestry SOE, and Korostyshivskey Forestry SOE (Central Polissya). Control samples were taken in plantations with similar forestry valuation features outside the sanctuaries. Sampling was performed in 2019 according to conventional methods from the 0-20 cm layer (NSU ISO 10381). Total humus was determined by Tyurin method (NSU 4289: 2004), pHSol. - potentiometric (GOST 26483-85). Soils of wet mixed broadleved forest conditions on the territory of the sanctuaries of hunting farms of Western and Central Polissya are characterized by low humus content $-1.90^{ \pm 0,44} \%(n=16)$ and a significant level of feature variation (coefficient of variation $V=47.7 \%$ ). Semi-free maintenance of game animals provided a positive tendency for the accumulation of humus during long-term operation of sanctuaries. Thus, in the soil samples taken in the sanctuaries of Sarnenske HF LLC, UTMR LLC, and Rys HFC LLC, the humus content was significantly higher compared to the samples taken outside the sanctuaries - the increase ranged from 41.8 to $58.7 \%$, which is connected not only with the flow of manure from wild animals, especially near the feeding grounds, but also the natural process of soil formation by humus-accumulative (turf) type. In the sanctuaries with a low degree of animal impact (Horodnytskey Forestry SOE and Korostyshivskey Forestry SOE), the difference between the samples on the content of humus is not fixed, or it is at the level of tendency improvement. The soils of the surveyed hunting farms are characterized by a strongly acid reaction $\left(\mathrm{pH}_{\text {сол. }}=3.77^{ \pm 0,24}\right)$. At the same time, the duration and intensity of the sanctuaries maintenance, as well as animal species within the studied objects had no significant effect on this indicator.

Keywords: humus-accumulative process in forest coenoses; reaction of the environment; type of forest site conditions; type of forest; semi-free maintenance. 